\title{
Challenges and Opportunities for Smallholder Farmers Participation in Teff Market in Ambo District, West Shoa Zone of Oromia, Ethiopia
}

\author{
Azeb Bekele Habtewolde \\ Ethiopian Institute of Agricultural Research \\ Ambo Agricultural Research Centre \\ P. O. Box 37, Ambo Ethiopia \\ Tadele Melaku Challa \\ Department of Rural Development and Agricultural Extension \\ Institute of Cooperatives and Development Studies \\ Ambo University \\ P. O. Box 19, Ambo, Ethiopia
}

\begin{abstract}
The study was conducted to investigate the extent of participation in the teff market and to identify the major challenge and opportunity teff production and marketing in Ambo district West Shoa Zone of Oromia. Two main teff producer Kebeles, namely Amaro and Gossu Kora were selected by using simple random sampling technique from 11 high potential teff producing Kebeles in Ambo district. A total of 142 teff growing households were selected using random sampling and then interviewed. The result indicated that the study areas are among the surplus teff producing Kebeles in the district and it was found that 50\% the market surplus obtained. Opportunities of teff production and market of the study areas are clearly identified which includes high demand of teff in the market, nearness to market, availability suitable climate and soil and high support and encouragements by the government. The main challenges observed in the study areas are lack of finance to invest; lack of improved farm tools; practicing very poor harvesting methods; shortage of land; high cost of production and low productively. It is recommended that farmers use modern technologies such as improved production methods, improved seeds, and farming tools; access to credit and labor reducing technologies to increase the supply of teff into the market. Moreover, reducing non-farm activities by making teff production more profitable and farmers must devote more time to farming activities. Further research needed on teff market chain analysis starting from producer to final consumers, and critical analysis on the value chain of teff.
\end{abstract}

Keywords: Ethiopia, Market participation, Smallholder farmers, Teff

\section{- Introduction}

Teff has become an important market-oriented crop in Ethiopia. It is reported that from total produced teff on average about $60 \%$ is supplied to market in three areas Adaa, Alaba, and Fogera areas (Berhanu and Hoekstra, 2007). However, the national average marketable surplus of teff is around $26 \%$, it varies from area to area for example in the Adaa area it was reported that only $75 \%$ of teff produced is supplied to the market. The remaining $25 \%$ is used for home consumption and seeds for the next sowing (Bekabil et al., 2011).

Market participation refers to the extent to which a household participates in the market as a seller (Jagwe et al., 2010). Participation' means any situation which involves the exchange of goods for money, regardless of location. 'Decision to participate' means whether the farmer engages in selling activities, regardless of the points of sales and quantities sold. 'Intensity of participation' means the quantity of the commodity sold by either party in a defined time period (Jagwe et al., 2010). Household market participation in crop output to markets is determined by household market orientation, the level of crop production, household, and household head characteristics, ownership of livestock, market access and institutional services (Jagwe et al., 2010).

Participation in agricultural markets by rural households is an important strategy for poverty alleviation and food security in developing countries (Heltberg and Tarp, 2001). Peasant farmer communities are among the poorest and the largest in developing countries, so policies that stimulate their interaction in the exchange economy will enhance economic growth (Mohammad and Asfaw, 2007).

There is a lot of research conducted on the marketing participation of smallholder farmers in different teff producing areas. Berhanu and Hoekstra (2007) conducted a study on teff, wheat, and rice to analyze the market participation of farm households, market actors, market channels and determinants of household market participation for these crops. 
This study attempt led to contribute to redressing this gap of knowledge on market information, determinant factor and market outlet choices for the three market-oriented cereal crops of teff (a grass-like staple food crop), wheat and rice. The study on the determinant of teff market participation indicated that about $60 \%$ of teff produce is sold, although there were significant variations among the districts. The proportion of teff produces sold ranged from $42-80 \%$. Results also indicated that in areas, where the proportion of cultivated area covered with teff was lower, a significantly higher proportion of teff produce was sold, indicating the relative role of staple food crops in market participation for a particular crop.

However, there is a little information about teff market participation that means information on factors affecting a farmer's decision to teff markets and the factors that affect the intensity of a farmer's participation particularly in the Ambo district were limited. Moreover, teff market outlet choices are not well understood in the major teff supply area like Ambo.

\section{- Research Methodology}

A mixed-method research design was used in this study. Both qualitative and quantitative data were used to answer the research questions. A qualitative method was used to collect qualitative data. A quantitative method was used to collect information that has been transformed into numbers.

The sample size was determined by using Slovin's formula (Slovin, 2003 as cited by Tadele et al., 2015).

$$
\begin{aligned}
& \mathrm{n}=\frac{N}{1+N e^{2}} \\
& \mathrm{n}=141.97 \approx 142
\end{aligned}
$$

Where: $\mathrm{n}=$ Number of samples

$\mathrm{N}=$ Total Population

$e=$ Error tolerance

Two main teff producer peasant associations (Kebeles), namely Amaro and Gossu Kora were purposely selected for this study in consultation with relevant agricultural officials from Ambo District Agricultural Office. These selected Kebeles are a relative better production potential of teff among other Kebeles in Ambo District. The two selected Kebeles have a total of 1553 households (HH). The numbers of sampled respondents are presented in Table 1.

\begin{tabular}{|c|c|c|c|c|}
\hline $\begin{array}{l}\text { Grain } \\
\text { type }\end{array}$ & $\begin{array}{l}\text { Name of } \\
\text { selected } \\
\text { Kebeles }\end{array}$ & $\begin{array}{l}\text { No of teff } \\
\text { Producing Head } \\
\text { Household }\end{array}$ & $\%$ & $\begin{array}{l}\text { No } \\
\text { Sample } \\
\text { Head } \\
\text { Household } \\
\text { has taken }\end{array}$ \\
\hline \multirow[t]{3}{*}{ Teff } & Amaro & 619 & 39.85 & 57 \\
\hline & Gossu Kora & 934 & 60.14 & 85 \\
\hline & Total & 1553 & & 142 \\
\hline
\end{tabular}

\section{Table 1. Number of sample respondents taken from each Kebeles}

A total of 142 respondents were randomly selected to collect primary data and information at the producer's level, for the present study. Among total respondents, teff growing farmers 57 households from Amaro Kebeles and 85 households from Gossu Kora were selected and interviewed.

Pre-tested and semi-structured interview questionnaires were used for collecting data and information from respondents. The interview questioners were formulated after a pilot survey in the study area by asking teff producers, development workers and agricultural officers in the district. Primary data was collected by using a personal interview technique from the producer. The validity of collected data and information were checked through focus group discussion with key informant using checklists. Data and information were collected by both student and enumerators with the direct supervision of student

\subsection{Descriptive Analysis}

The descriptive method of data analysis includes the use of ratios, percentages, means and standard deviations in the process of comparing socioeconomic, demographic and institutional characteristics of households. Analyses were used to the average quantity of teff produced per sample households and the amount of teff marketed surplus with market participation by producers. This analysis is chosen because it helps to identify the quantity of teff supply to the market and extent of participation by producers. 


\section{- Result and Discussion}

\subsection{Major Actors and Roles of Teff Market Participants}

Difference market actors are involved in supply teff from producers to consumers. Six main market chain actors were found to be involved in the teff market chain in the Ambo area particularly in Gossu Kora and Amaro Kebeles. These are farmers, wholesalers, retailers, brokers, cooperatives, and consumers. It is reported that teff growing farmers mainly sell their produce to wholesalers (60\%), and direct to consumers (24\%) (Figure 1). Remaining 12\%, 3\% and $1 \%$ were sold to retailers, brokers, and cooperatives, respectively. This indicated that final consumers can get teff through different market chain. Only one-fourth of the teff growing farmers in the study areas had supplied their product to consumers. Very few were selling to their cooperative union.

\section{Figure 1. Farmer's market outlet}

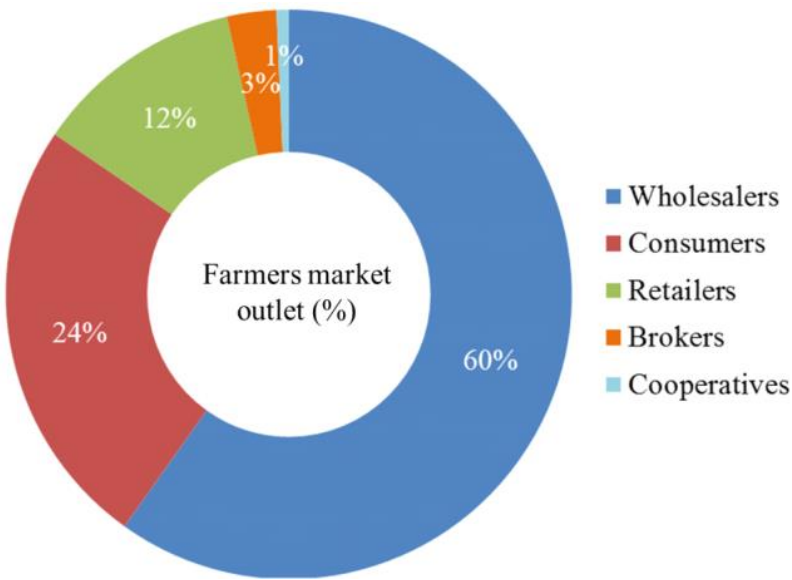

Producers are farmers and produce teff and they are the first link in the marketing chain. Farmers produce and harvest their teff crops. They transport grain to the nearest markets using pack animals over a distance. They had several marketing options, selling directly to consumers or selling to wholesalers. Alternatively, farmers also sell their products directly to cooperatives and retailers. Farmers sell their teff through different channels. In the study areas, the channels were wholesalers, consumers, brokers, retailers, and cooperatives.

Wholesalers: are traders who have a permanent market place or stores and may or may not move from one market to another to buy and resale grains. The result showed that about $60 \%$ of teff is sold to wholesalers in the study areas.

Retailers: Retailers are persons that sell the commodity to end-users. The majority of grain retailers in the study area are characterized by, no stores and weighing scale, often trading grains purchased from wholesalers and about $12.0 \%$ farmers' teff is sold to retailers at the local market or Ambo town market.

Brokers: are agents who work for a commission on behalf of other participants. They specialize in bringing the buyers and sellers together. They disseminate price and other information to the market participants sometimes buying teff products. In the study area, only $2.8 \%$ of the producers sell their products to brokers.

Cooperatives: Cooperatives as a form of business organization are distinct from the more cooperatives help to sell their members' farm products and maximize the return that they receive for these goods. Marketing cooperatives can serve their members in many ways, including information about market price financial support; storing and selling members' grain. Two unions are present in both Kebeles with the objective of increasing farmers' bargaining power and to benefit them from economies of scale. As the sample households explained in 2014 crop year cooperative unions used to purchase $1 \%$ teff product directly from members and non-members in their locality.

Consumers: are final consumers and those who make food from teff product for direct use by themselves or to sell enjera which is prepared from teff product to their customers in the restaurants or another market participation

\subsection{Production and Marketing of Teff}

The production of teff is the main source of cash for farmers in the Gossu Kora and Amaro areas. Teff is only produced once in a year because of rain-fed agriculture and crop need very moist soil. The volume of production of teff and supply to the market is presented in Table 2. The difference in the volume produced and supply to market in respondents households may be influenced by differences in resource endowments such as land size and differences in the use of productivity-enhancing inputs such as fertilizer and improved varieties as observed earlier. It may also be a reflection of the increased volumes in production, which generated a more marketable surplus. 
Table 2. Average Production of teff by households (in quintal per hectare)

\begin{tabular}{llllll} 
Variables & Obs & Mean & Std. Dev & Min & Max \\
\hline $\begin{array}{l}\text { Quantity produced per } \\
\text { HH (qt) }\end{array}$ & 142 & 15.99 & 7.89 & 2.13 & 40 \\
\hline $\begin{array}{l}\text { Amount marketed per } \\
\text { HH (qt) }\end{array}$ & 142 & 7.99 & 3.94 & 1.06 & 20 \\
\hline
\end{tabular}

The average quantity of teff produced per sample households was 15.99 quintals as reported in the study area which is slightly higher than the national average i.e. 15.75 (CSA, 2015). Besides this, the research result by Tadele et al. (2015) in Dendi district also indicated that average productivity 16.87 quintals per hectare teff is reported in the study area which is exclusively larger than the national average i.e. 15.75 quintals per hectare (CSA, 2014/2015) as compare to west Shoa zone yield i.e., 18.67 quintals per hectare (CSA, 2014/2015). The yield is not exclusively larger than the west Shoa zone of Oromia. This indicates that teff productivity is low in the study area

It is assumed that the supply of teff exceeds demand in the immediate post-harvest period. The glut during harvesting season reduces producer prices. For much of the remainder of the period before the next harvest, the product is usually in short of supply, with traders and consumers having to pay premium prices to secure whatever scarce supplies are available in the market. About $44.37 \%$ of the consumers highly demanded teff products during harvesting time because of reduces price due to high supply of teff in a marker. However, $77.46 \%$ producers want to sell teff products the period before the next harvesting (July to October) because of higher price of teff. This is mainly low supply of teff in the market and high demand in these periods of the year.

\subsection{Producers' Price-setting Strategy}

According to the survey result, about $59.86 \%$ of sample households reported that the market price set by the farmers themselves (Table 3). However, $30.98 \%$ of respondents reported that market price was set by the wholesaler and 7.75 $\%$ of respondents believed that market price determined by the collectors. The remaining $0.71 \%, 0.70 \%$, and respondents reported that the selling price of the product was set by a broker and retailers, respectively.

Table 3. Teff price setting

\begin{tabular}{ll}
\hline Teff price setting & Percent \\
\hline Farmers & 59.86 \\
\hline Wholesaler & 30.98 \\
\hline Collectors & 7.75 \\
\hline Broker & 0.71 \\
Retailers & 0.70 \\
\hline
\end{tabular}

Even if the majority of farmers set market price but the level of satisfaction is very different among respondents. It was reported that majority (79\%) of farmers are satisfied by the price of teff selling in the market and the remaining $21 \%$ of the producers are unsatisfied at the selling price of teff with respect to your cost of production (Figure 2). This indicated that the majority of the teff producer farmers are happy in market price because the price is reasonable to cover the cost of production. On another hand, some are unsatisfied with the market price and they reported that the price is low as compared with the cost of production expanded and as a result, they get less profit.

Figure 2. Farmers perception towards teff price

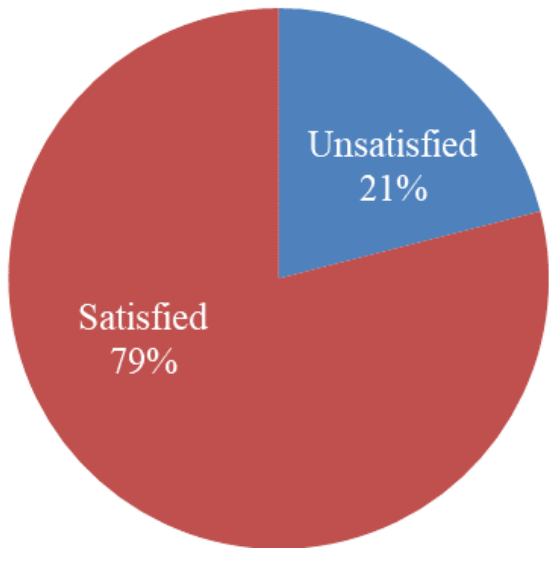




\subsection{Opportunities and Challenges in Teff Market Participation}

It was pointing out the main opportunities and challenges of production and market supply of teff in the study areas. The areas have a high potential for teff production and market supply such as high demand in the market, nearness to a major market, high government support and suitable climate for production.

However, there were challenges facing the producers in related to teff production and market supply like lack of finance to invest, lack of improved teff seed, lack of improved production tool, using very poor harvesting methods and device, shortage of land, low productivity and the high cost of production.

According to Adeleke et al. (2010), smallholder agriculture in the four East African countries has been facing numerous constraints. While some are unique to each of the countries, most are of a similar nature, implying that common solutions would address them across countries. The constraints discussed below are not new, but rather longstanding and perhaps even chronic. In addition to smallholder farmers, the constraints to some extent also impact largescale or plantation farmers.

\subsection{Opportunities for Revitalizing Smallholder Agriculture on Teff Market Participation}

Teff production and its market supply in Ambo areas by smallholder agriculture have numerous opportunities, which are presented as bellow:

\section{Rising demand in the country and global level}

There is an increasing trend in demand for teff crop in the country and global level, particularly in developed countries. Since the study areas are very near to Ambo town and the Ambo population increased as fast rate these two factors make teff highly demanded currently. Generally, main driven factor in the country is a fast increment of population growth, has created opportunities for the expansion of teff production. Increased demand would be followed by a better farm price for producers. It has been described the importance of teff in the literature previously; teff has increased noticeably due to its very attractive nutritional profile and gluten-free nature of the grain, making it a suitable substitute for wheat and other cereals in their food applications as well as foods for people with celiac disease.

\section{Suitability of the area for the production}

Ambo area is one of the suitable areas for teff production in the country. The presented results have shown that the majority of respondents were having a mixed type of land which means the nature of the land is not steeps or plain. It is some of the natural endowment opportunities in the areas. These opportunities are important for the growth of grain annual crops like chickpea and grass pea. Furthermore, a mixed type of land farming has a potential contribution to livestock production. The area is favorable for teff production than any other agricultural activity. Farmers ready to accept new technologies who having better landholding than the average farmer in Ethiopian (Muhammed, 2011).

\section{Government suitable agricultural policies designed to support farmers at the grass-root level}

Current government policy and strategies give due attention to agricultural transformation and development of basic infrastructures like road development, communication, and telecom services outreach throughout the country, particularly in rural areas. Extension services in the agricultural sector and support and encouragement for model farmers are putting as a main agricultural development strategy. The assignment of development agents at each Kebeles based on their academic background is also important policy dimensions. Furthermore, provision of infrastructure facilities like roads, telecommunication (mobile, wireless, and optic fiber), power supply and financial institutions as banks, micro finances institutions are the infrastructural advantages that facilitate the production and marketing of teff in the study areas.

\subsection{Challenges of Teff Production and Marketing by Sampled Household.}

Teff producer farmers in the study areas face a number of constraints in teff production and supply to the market. The major constraints of teff production and marketing are described as below:

\section{Lack of finance to invest}

For investment, smallholder farmers in the two Kebeles depend on savings from their low incomes, which limits opportunities for expansion on farming. For example, a survey of a sample of 142 rural households in Ambo in the year of 2014 that half of the total rural household income came from farming, 47.18\% from non-farm because of the lack of collateral and/or credit history, most farmers are bypassed not only by commercial and national development banks, but also by formal micro-credit institutions. In addition to own sources, farmers thus rely on incomes of friends and relatives and informal money lenders.

As indicated by Adeleke et al. (2010) in Kenya, Tanzania, and Ethiopia the share of commercial banks' loans to agriculture has been very low compared to manufacturing, trade, and other service sectors. It is hampering expansion and technology adoption. For example, in Kenya, lack of capital and access to affordable credit is cited by smallholders 46 
as the main factor behind the low productivity in agriculture. Access to formal credit in Tanzania and Ethiopia is mainly confined to large urban centers, where collateral requirements are high. In Uganda, high-interest rates inhibit agricultural investments Adeleke et al. (2010).

Similarly, the presented survey result indicated that $80 \%$ of respondents reported that the probable constraint of teff production was a lack of finance to invest in teff production, however, the remaining $20 \%$ reported not as such problem. This clearly indicated that lack of finance is a major problem in teff production and this problem may be one of the reasons for the low productivity of the crop.

\section{Lack of improved teff seed}

Even if $71.13 \%$ of the respondents used improved seeds, the seed source is not certified. About $80.99 \%$ of respondents reported that the seed used for last year sowing was not from certified sources like Ethiopian Improved Seed Agency or research centers. However, the remaining $19.01 \%$ of farmers were reported that used certified improved seed sources. It is clear that in Ethiopia agricultural improvement has been a focus on smallholder farmers through improved access to modern inputs like improved seeds and fertilizer. However, delivery systems have not performed as expected, which has caused delays in the procurement and distribution of inputs (Adeleke et al., 2010). The present study clearly indicated farmers in the study areas do not get seeds from certified sources. It is believed that it is one of the main challenges for teff production in the Ambo area. Moreover, for those who used improved seeds, their sources are local farmers by exchanging or using previously used seeds or purchased from neighbor farmers. This kind of source of seeds may not be pure as the seeds delivered from the National Seed Agency or from research centers.

\section{Lack of improving production tool and very poor harvesting methods and device}

The survey result indicated that $66.90 \%$ of the sample households reported a lack of improving production tools as the constraint of teff production in two sampled Kebeles. However, the remaining 33.10\% of respondents reported that the lack of improving production tool is not as such a challenge for the producer. It was also about $57.04 \%$ of respondents reported that poor harvesting method combined with a lack of improves devices was a challenge for teff production. All farming and postharvest activities of teff production have done by traditional methods of farming by using traditional tools. For instance in threshing and winnowing practiced in very traditional and backward methods. These methods and practices of production may cause high post-harvest loss and contribute to low yielding teff.

\section{Shortage of land}

Constraint related to unequal access to land is one of the challenges of teff production in the study areas. The survey result indicated that $14.79 \%$ sample household is landless using farming activity acquiring land in a different way by rental or crop sharing agreement. Inadequate access to land has been a critical challenge to smallholder farming in East Africa (Adeleke et al., 2010). These problems can be examined from a different perspective. As discussed earlier, the average landholding of sample households in the study areas was 3.27 hectares and the average family size of 5 persons. It would not be enough to supply to market besides feeding the whole family. That is why $64.79 \%$ of the sample households reported that shortage of land as a major problem.

\section{The high cost of production}

The presented survey result revealed that $46.48 \%$ of sample respondent farmers reported the high cost of production has been a constraint on teff production. However, 53.52\% of respondents were reported that the high cost of production not as such problem for teff production. The main reason for the rise in cost of production as farmers indicated that increase the price of farm inputs year to year. This increment makes high cost of production on teff. The high cost of production on the input side, the average application rates of fertilizer for arable crops in four countries are estimated to be $30 \mathrm{~kg} / \mathrm{ha} / \mathrm{year}$ in Kenya, $14 \mathrm{~kg} / \mathrm{ha} /$ year in Ethiopia, $5 \mathrm{~kg} / \mathrm{ha} /$ year in Tanzania and $1 \mathrm{~kg} / \mathrm{ha} / \mathrm{year}$ in Uganda. These were far less than the world average of $100 \mathrm{~kg} / \mathrm{ha} / \mathrm{year}$ (Smaling et al., 2006 and Ariga et al., 2006). There is also the problem of high cost and waste of key inputs such as seed and fertilizers. For this reason, farmers have substantially reduced the use of quality and appropriate inputs such as seed, fertilizer, and pesticides.

\section{- Summary and Conclusions}

The study was conducted in the Southwest part of the Ambo district. The district was purposively selected for its potential in market-oriented agricultural commodities like teff. A total of 142 farmers were interviewed. Generally, in this study, descriptive analysis was used to analyzing the data using STATA 12. The main findings of this study are summarized as follows. The average family size of farmers participating in the survey was 5 members with productive age, the average years of farming experience for total sample households were $18.15 \%$ years. Out of the total sample households, $47.18 \%$ were involved in non-farm activities. The mean quantity of teff produced per sample households was 15.99 quintals are reported in the study area and the average household sold about 7.99 quintals per year of its total production in value terms which means about $50 \%$. 
This is an indicator of if the farmers increase production by one present marketable surplus increased by half in the study areas despite the unique advantage of their proximity to the one largest city in the region, Ambo. In absolute terms, the average household sold crops amounting to Birr 9,178.52 per annum (approximately USD 437.00).

Opportunities for teff production the study area is clearly identified. It was reported that increasing demand for teff in the market and it is showed an increasing rate of time to time, availability of suitable climate and soil in the area for teff production. Current government policy and strategies give due attention to agricultural transformation and development especially in a market-oriented crop like teff. This all opportunities are supporting factors to increasing teff production and supplying market and then increase participation in the study area.

The major challenges of teff production and supply to the market in the study areas also identified which includes lack of finance to invest, lack of improved teff seed, lack of improving production tools, very poor harvesting methods, shortage land, the high cost of production and low productively are also main challenges factors reported in teff production.

In general, a number of actions need to be undertaken in order to promote the development of teff production and market participation. This particularly includes capacity building, technological applications: like improve seed, improve production tool and improving harvesting methods and the device it helps to reduce the post-harvesting loss of teff product and reduce the time of production and labor. Agricultural extension agents and cooperative have integrated the provision of market information. Infrastructural development is also a key to support the sub-sector. In this area, emphasis should be given to the transportation system and offer credit and other services to improve effective teff production and marketing.

\section{- Recommendations}

Several measures need to be implemented to solve the problems of smallholder teff producing farmers to improved production and market supplying. In particular, access to land, increasing access of credit, access of farmers to improve seed, providing improved production tools and improving harvesting methods and devices, encouraging farmers' by training to use the modern methods of production. It should be given efforts on improving infrastructure, which can play an important role to increase in teff productivity and also market participation.

\section{References}

Ariga J., Jayne T.S., and Nyoro J. (2006) "Factors Driving the Growth in Fertilizer Consumption in Kenya, 19902005; Can the Momentum be Sustained?", Paper presented at Tegemeo Agricultural Policy Conference Safari Park Hotel, Nairobi May 18, 2006.

Berhanu, G. And Hoekstra, D. (2007) 'Cereal Marketing and Household Market Participation in Ethiopia: The Case of Teff, Wheat and Rice', In AAAE Conference Proceedings Cereal Marketing in Ethiopia, Pp. 243-252.

CSA (Central Statistical Agency) (2015) Agricultural Sample Survey, Addis Ababa, Volume I (Private Peasant Holdings, Meher season)

Heltberg. R. and F. Tarp. (2001)“Agricultural Supply Response and Poverty in Mozambique. "Presented Paper at the Conference on Growth and Poverty at WIDER. 25-26 May 2001, Institute of Economics, University of Copenhagen.

Jagwe J, Machethe C, Ouma E. (2010) Transaction costs and smallholder farmers' participation markets in the Great Lakes Region of Burundi, Rwanda and the Democratic Republic of Congo. Afr. J. Agric. Res. 6(1), pp. $1-16$.

Mohammad, J. and Asfaw, N. (2007) Dairy Market Participation with Endogenous Livestock Ownership: Evidence from Cote d'Ivoire. International Livestock Research Institute.

Muhammed, U. (2011) Market Chain Analysis of Teff and Wheat Production in Halaba Special District, Southern Ethiopia, M.Sc. Thesis, Haramaya University.

Salami, Adeleke; Kamara, Abdul B.; Brixiova, Zuzana (2010), Smallholder Agriculture in East Africa: Trends, Constraints and Opportunities, Working Papers Series $N^{\circ} 105$ African Development Bank, Tunis, Tunisia

Smaling E., Toure M., Ridder N., Sanginga N. and Breman H. (2006) Fertilizer Use and the Environment in Africa: Friend or Foes?, Background Paper Prepared for African Fertilizer Summit, June 9-15, Abuja, Nigeria.

Tadele, M., Mulu, D., and J. Poul, M. (2015) Determinants of teff and wheat market supply in Dendi District, West Shoa Zone, Ethiopia Prime Journal of Social Science, 4(10), PP.11224 - 1130 